\title{
EXCURSION TO NEWTON ABBOT, CHUDLEIGH, DARTMOOR, AND TORQUAY,
}

\section{EASTER, 1900.}

Directors: Horace B. WoOdward, F.R.S., F.G.S., A. R. Hunt, M.A., F.L.S., F.G.S., AND W. A. E. UsSher, F.G.S.

Excursion Sectetary: Percy EMARY, F.G.S.

(Report by The Directors.)

I.-Newton Abbot, Bovey Tracey, and Chudleigh.

BY H. B. WOODWARD.

DuRing the Easter excursion of 1899 the members of the Association examined for the first time the coast of South Devon from Seaton to Exmouth, and proceeded from Exeter as far as Great Haldon.* On the present occasion they investigated a further portion of South Devon, to which no excursion had previously been made, except on one occasion, July z 3 rd, 1884 , when, under the guidance of William Pengelly, and during the presidency of the late Dr. Hicks, the members proceeded from Plymouth to Torquay for the day, saw the coast at Hope's Nose, and visited Kent's Cavern.t

On Thursday evening, April 12th, the members of the party arrived at the Globe Hotel, Newton Abbot.

On Friday, April 1 $3^{t h}$, they started at nine a.m., and were driven through the old town of Newton Bushel to the hill on which Knowles Quarry is situated. Here was to be seen an intrusive mass of ophitic dolerite or diabase (with chlorite), which had produced a spotted alteration termed "Spilosite," on the adjacent Upper Devonian slates. Much of the diabase was in a decomposed state, and the Director remarked that it was a good instance of the rotten nature of much of Devonshire, a state due to prolonged weathering, and which added greatly to the difficulties of geological mapping. The igneous rocks formed many isolated knolls in the district, and this appeared to be due not altogether to their hardness, but partly to their porosity after decay. They rose up like outliers of Bagshot Sand in a London Clay area. Nevertheless they had their uses, for while the solid rock at a depth provided road-metal, the deeply-rotted portion was a water-bearing bed, and gave out springs. Among the fossils noted from the slates by Mr. Ussher were Posidonomya venusta, Trilobites of the genus Phacops, and Ostracods. The beds belonged to the division known as the Entomis-slates (or Cypridinen-schiefer).

* Proc. Geol. Assoc., vol, xvi, p. 133.
+ Proc. Geol. Assoc., vol. vili, p. 472.

Proc, Geol. Assoc. Vol. XVI, Part 8, JULy, 1900.] 
The party was then driven on by Blatchford and Forges Cross to Sandpit Copse, south of Lower Staplehill. Here, at an elevation of 223 feet, was a sand-pit showing highly-inclined beds of sand and gravel, with pipe-clay and traces of coloured clays, dipping towards the Bovey valley at an angle of about $35 \mathrm{deg}$., and resting against Devonian slates. The grave! yielded fragments of veined grit, chert, igneous rocks, and more rarely Greensand chert and Chalk flints. This was one of the sections referred to by Mr. Clement Reid in his paper on the Eocene deposits of Devon.

Driving on by Blackpool and Halford, the members were now conducted to the old Lignite Pit by the Bovey Tracey Potteries; a pit rendered famous by the researches of the late William Pengelly and Oswald Heer. The pit was partially filled with water, but the banks showed fine white sandy clays, coloured clay, and coarse sands, with thin flaky lignite bands.

The lignite had been worked since about the year I 7 I 4, and was known as the Bovey coal, the thickest bed being about six feet. When burnt, it gave out much smoke and an unpleasant odour. Dr. Falconer had first suggested that the lignite-beds might be of Miocene age, and. through his influence, Pengelly started his explorations with the aid of Mr. Henry Keeping. The section was then cut clear, and they were enabled to examine over Ioo feet of the strata which dip to the south at $5 \mathrm{deg}$. The plant-remains were examined by Dr. Heer, who regarded them as Miocene, and as akin to those of the Hempstead (Hamstead) Beds of the Isle of Wight. More recently Mr. J. Starkie Gardner had shown that the flora was practically identical with that of the Bagshot Beds of Bournemouth. The lignite was mainly composed of coniferous wood, and among the species identified, the Sequoia couttsice was noteworthy. The oaks, laurels, figs, and cinnamons of Bovey were identical with those of Bournemouth.* No animal remains, with the exception of one insect, had been found in the deposits.

As originally pointed out by De la Beche, the strata had been deposited in a large lacustrine area, the clays (an impure chinaclay) being due to the decomposition of the felspars, and the sands being derived from the quartz of the Dartmoor granite. $\dagger$

Driving across Bovey Heath, the members next visited the large clay-pit belonging to Messrs. Candy \& Co., at the Great Western Potteries, near Heathfield Station. Here a variable series of grey and white clays, carbonaceous sands, and occasional lignite-beds was to be seen. It was mentioned that a boring had been carried to a depth of 520 feet from the surface through clays, sands, and lignites without reaching the base.+ The beds here

\footnotetext{
* Gardner, Geol Mag., dec. ii, vol. vi, p. I53; Quart. Fourn. Geol. Soc., vol, xxxv p. 227 ; xxxviii, p. 3 .

+ "Report on Geology of Cornwall," etc., pp. 255, $5 \mathrm{Il}$.

I A boring made more than sixty years ago near Bovey Tracey passed through nearly, 300 feet of Bovey Beds.-De la Beche, op. cit., p. 248 .
} 
dipped at an angle of about $8 \mathrm{deg}$. towards the W.S.W. At this pit, Messrs. Candy \& Co. manufactured all kinds of sanitary ware, white and coloured glazed bricks, fire bricks, etc.

Elsewhere in the Bovey basin the white pipe-clays and the darker potters' clays were dug and shipped from Teignmouth, not only to the potteries of North Staffordshire, but to various parts of Europe. In I 898 , nearly 38 , 000 tons of clay were dug, the total value being estimated at a little over $\mathcal{E}_{1} 8,000$.

Attention was drawn to the fact that the surface-layers of the Bovey deposit had here and there been rearranged and redeposited in Pleistocene times, as proved by the discovery, made in 1872 by Dr. Nathorst, of Betula nana, the dwarf arctic birch. These remains had been found in the surface deposits in a pit between the Bovey Tracey potteries and those of Heathfield. It was also stated that remains of a canoe had, in $188 \mathrm{I}$, been found in the Heathfield pit, and attention had been drawn to the discovery by Pengelly, who thought that the object was of Glacial age.* There was, however, no reason to assign so great an antiquity to the canoe, for, although the surface was a little over go feet above sea-level, and perhaps 40 feet above the level of the adjacent Bovey river, in ancient times there were doubtless pools and boggy places in the broad Bovey valley in which a canoe might have become mired. Indeed, J. G. Croker had remarked in 1856 that, until within the previous ninety years, when it had been arained, the Bovey basin had been almost a swamp. $\dagger$ Moreover, during February, in the present year, exceptionally heavy floods had occurred in the valley, so that the road between Kingsteignton and Newton Abbot became impassable, owing to a heavy snowfall and subsequent thaw, accompanied by heavy and continuous rain. In the old alluvial gravel of the Teign, at the Zitherixon pit, which lies a little west of the road just mentioned, there were discovered, many years ago, a wooden doll (possibly an emblem of phallic worship) and also a bronze spear-head, objects which were kindly exhibited at the Globe Hotel, by Mr. C. D. Blake, of Newton Abbot.

Crossing the river Bovey and the Teign at New Bridge the party was now driven to a newly opened lignite-pit in the "Great Plantation," east of Preston Manor clay works, and a little to the east of the high road between Chudleigh and Newton Abbot. Here an excellent section of the lignite-series with bands of potters' clay had been opened up in proximity to other pits where pipe and potters' clay were extensively dug for Messrs. Watts, Blake, Bearne $\&$ Co. The lignite was used for fuel in the stationary engine which worked the machinery employed in the pits. There was no time for a detailed study of these lignite-beds, but the illustration (Plate XII, Fig. 2), from a photograph taken by Mr. A. K. Coomara Swamy, well shows the alternation of potters' clay and lignite.

* Trans. Devon. Assoc, vol. xv, pp. 376, 395 .

$\dagger$ Quart. Journ. Geol. Soc., vol. xii, p. 354 . 
Mr. Bauerman remarked that the lignite was somewhat similar to the Brown Coal of Tertiary age, worked in various localities on the Continent.

Returning by the high road the members were now driven by Bellamarsh Barton, where, alongside the river Teign, sections of disturbed Culm-measures were to be seen. Alighting near Chudleigh Station, the members were met by Mr. W. A. E. Ussher, who now took up the duties of Director, and also by Col. Walcott, of Rock House. Walking by Lawell House and across Kate Brook, a small section of cherty beds in the Lower Culmmeasures was examined. This showed about 12 feet of dark chert beds of the Basement Culm-measures, in which Messrs. Fox and Hinde had found Radiolaria.* Mr. Ussher pointed out the structure of the Chudleigh valley, where the Devonian slates and limestones occur bounded on all sides by faults, bringing them against different portions of the Culm-measures. In the Chudleigh gorge he remarked that the relations of the Devonian slates and limestones were apparently due to the exposure of slates by denudation of the overlying limestones; this however, he considered illusory as the slates seemed to be of later formation than the limestones, and the latter, if not overthrust upon them, would appear to have been formed by coralline growths in clear water at a more rapid rate than the muddy sedimentation which was afterwards slowly accumulated on their margin, so that beds of slate of Upper Devonian age might be banked against limestone of the massive type either of the zone of Rhynchonella cuboides or of indisputably Middle Devonian age. This explanation, he said, had been put forward by him ten years ago, to account for phenomena such as the relations of the slates and limestones of Chudleigh gorge, and the outer edge of the Newton Abbot limestones near Chircombe Bridge at their junction with slates. ${ }^{+}$The Chircombe Bridge limestone was considerably lower in the series than the Chudleigh limestones, and again the Ashburton limestone was separated from the Newton Abbot limestones by slates in part corresponding to the Cypridinen-schiefer, and containing the characteristic Ostracoda of that Upper Devonian group. Hence the connection of the Ashburton and Newton limestones not only demanded a synclinal structure, but also considerable difference in rates of organic growth and muddy sedimentation, unless the limestones were bounded by faults, of which there was not sufficient evidence.

Having proceeded a short way up Chudleigh Glen, the fine crags of Devonian I Limestone and the entrance to one of the Chudleigh caves were seen. Col. Walcott then led the party through his picturesque grounds, in which an old quarry and another cavern are situated; then a halt was made at Glen

* See Trans. Devor Assoc. vol. xxix, 1897 , p. 588.

+ Quart. Journ. Geol. Soc., vol. xlvi, p. 513 . 
Cottage, adjacent to the Palace quarry, and a little above the Chudleigh waterfall. In this quarry fine examples of Murchisonia have been obtained.

Mr. Woodward exhibited specimens of Rhynchonella cuboides and Heliolites porosus, examples of which had been obtained from the Chudleigh quarry.

Mr. Ussher remarked that the occurrence of the Frasnian (lower part of Upper Devonian) shell in the same quarry with the Middle Devonian coral, was parallelled in other well-known quarries, such as those of Wolborough and Lummaton. It appeared that the massive limestones of the Torquay, Chudleigh, and Newton district, which in the Lower Dunscombe quarry and at Petitor were immediately overlain by shaly, irregular, livercoloured limestones, containing Upper Devonian Goniatites, such as $G$. intumescens and $G$. sagittarius, represented the basement Upper Devonian beds of the Continent, viz., the massive limestones of the zone of Rhynchonella cuboides, but in Devon there was a blending of Middle and Upper Devonian forms in them. If there were not a blending the fact of the discovery of fossils characterising different horizons in the same quarry must be ascribed to plications which in the massive limestones cannot be traced, but are nevertheless scarcely ever absent from the Devonshire Devonian rocks.

Driving then through the town of Chudleigh, and down the narrow street by the Town Mills to Biddlecombe Cross, the members again alighted, and walked eastwards to the lane leading downhill towards Waddon Barton. Here they examined the lower beds of Culm-measures, rendered classic by the labours of the late J. E. Lee and Dr. Henry Woodward. The section was somewhat overgrown, but the party succeeded in bringing to light many specimens of the characteristic even-bedded reddish brown stone, which being split along the direction of the bedding surfaces, revealed traces of the characteristic Goniatite, G. spiralis, portions of Phillipsia, and traces of Posidonomya. Mr. Ussher showed the position of the beds in faulted contact with the prolongation of the Chudleigh limestone on the north and south, the limestone on the south side passing under green Upper Devonian slates at Waddon Barton.

The time spent in exploiting the lane unfortunately necessitated the abandonment of the visit to the lower Dunscombe quarry which, situated between converging faults, is very near Waddon Barton lane. There the "Goniatite-Beds," red shales and limestones with Goniatites intumescens, overlie limestone with Rhynchonella cuboides, etc.*

Rejoining the carriages, the party was now driven through the picturesque grounds of Ugbrooke Park, by kind permission of

\footnotetext{
* Qwart.Journ. Geol. Soc., vol. xlvi, pp. 507, 5 II
} 
Baron Clifford of Chudleigh. The conglomeratic sandstones of the Culm-measures were noticed by some of the members.

Passing Babcombe, a halt was made at Fosterville, and most of the members, under the guidance of Mr. Woodward, walked by a pleasant lane and then across country, through woodland, moor, and marsh, to the Lappathorn Clay pits, and on to Abbrook. Here evidence was seen of the interbedding of gravel with the white clays of the Bovey Beds, the whole overlain by a head of coarse ferruginous gravel which became thicker towards Abbrook, and appeared to be rearranged gravel, not, however, far removed from its parent source. From Abbrook, the party was driven through Kingsteignton to Newton Abbot.

\section{II.-Lustleigh and Dartmoor.}

By A. R. Hunt.

On Saturday, April I4th, the members took the 9.43 a.m. train from Newton Abbot to Lustleigh. [At Newton Abbot they were joined by Mr. and Mrs. A. R. Hunt, Bishop Mitchinson, the Rev. G. F. Whidborne, and Mr. A. Somervail.] Leaving Lustleigh Station, they proceeded by Rudge and Hisley to the weir near the junction of Becka Brook and the River Bovey. A halt was called at Rudge, to point out the railway-cutting in which the Culm rocks come into abrupt contact with the fine schorlaceous granite commonly known as elvan. In Hisley Wood, the party passed from the ordinary Dartmoor granite over an obscured junction to the Culm. A quarter of a mile beyond the weir, the Becka Brook was crossed by a footbridge near the point of Houndtor Ridge, a remarkable arête of Culm grit dividing the valleys of the Bovey and the Becka. The ascent of the Ridge, some 500 feet, along a steep and narrow pathway, afforded beautiful views on either side. It was pointed out that both the quartz-veins and elvan-veins in the Culm shared with the main granite and elvan the characteristic of containing fluid inclusions with chlorides. At the summit of the Ridge (Water Rock on the old I-inch map, nearly 800 feet above sea-level) the Culm rock is intersected by numerous elvan veins which were carefully examined.

Leaving Water Rock, the party proceeded by Becka falls, and the Rev. Preb. Wolfe's private drive (by kind permission), to Houndtor, noticing on the way a remarkable contact of fine and coarse granite in a roadside block, and some torrential rubble drift between Leighon and Houndtor farm. Arrived at Houndtor, luncheon baskets and sandwiches were in immediate request, after which the party climbed to the top of the tor, which is about r,200 feet above sea-level. Several Dartmoor questions were forthwith discussed. 

and

The Director made some observations on the origin of tors,

Mr. Teall (President of the Geological Society) discoursed on the petrological characters of the Dartmoor granite.

Mr. Woodward remarked that not far off, near Hay Tor (or Heytor), there had been an iron mine where magnetite occurred interstratified with the altered shales and sandstones of the Culmmeasures. According to Prof. Le Neve Foster, the iron-ore, originally brown hæmatite, had been altered by the granite, as also had the associated strata. The altered rocks contained hornblende and actinolite, garnets, pyrites, etc., also a mineral named Haytorite, which was chalcedony pseudomorphous after datholite.*

Mr. Somervail drew attention to the fact that in the great expanse of Dartmoor, where there were no distinct evidences of glacial action, there were no tarns, whereas such sheets of water were common in the glaciated regions of Scotland. $\dagger$

Mr. IV. P. D. Stebbing referred to the discovery of blocks of granite in the Chaik of the south-east of England. It had been suggested that some of these boulders had come from Dartmoor, but Prof. Bonney considered this place of origin most improbable.

The members now proceeded across the moor to a granite pinnacle known as Bowerman's Nose, and the opportunity wa. taken to photograph the rocks. The accompanying view (Pl. XII, Fig. I) is from a photograph by Mr. H. Preston. Thence the route led through Wingstone and Manaton (Haif Moon) to Foxworthy [the country cottage belonging to Mr. and Mrs. Hunt, where an excellent tea had been most kindly provided].

The Director, with the vanguard of the party, pressed on to examine some large mounds of rounded rubble in Peck Pits, and also a Hut circle. The field which contains this Hut circle is called the Maryhay - a curious survival of Saxon times, viz., the "merihay" or boundary hedge. It still is the boundary hedge, and the only non-natural boundary of the little farm on the east side of the river.

Many Hut circles have been observed on Dartmoor, and they are regarded as foundations of early habitations. Some of them had stone walls four or five feet high, which were used probably to support wooden poles and a roof of rushes. Flint flakes, scrapers, and cooking-stones have been found in the Hut circles, but no metal implements and no pottery.

A hearty vote of thanks having been accorded to Mrs. Hunt, the return journey was made by Raven's Tor and Lustleigh Cleave to Sharpitor, the Nut Crackers (a logan stone), and Lustleigh Station.

On the way the party first inspected a felspar-quartz-schorl

* Quart. Joum. Gesl. Soc., vol. xxxi, p. 628.

+ Trans. Dezion Assoc, vol. xxix, p. 386 . 
vein in situ, the minerals being those of the elvans, but the structure not granitic.

Then two small but deep rock-basins attracted attention. Similar to pot holes in streams, these basins were clearly formed by the solvent action of rainwater, probably acidulated by the decay of lichens and other vegetation.

Lastly, a split block of granite attracted much attention, presenting as it did an exceptional number of Dartmoor problems, such as concretions of two sorts, latent planes of weakness, dissolution of orthoclase crystals, twin crystals of orthoclase, and rearrangement of minerals.

\section{III.-WATCOMBE.}

BY H. B. WOODWARD.

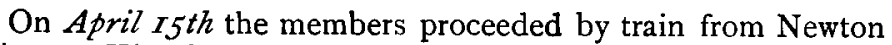
Abbot to Kingskerswell, whence the road was taken by Kingskerswell Cross and Barton Cross to the Mincent Hill quarries at Barton. Here the Devonian Limestone was well exposed, and yielded numerous corals. From this locality and the adjoining quarries at Lummaton, the Rev. G. F. Whidborne had obtained many fossils, figured and described in his Monograph, published by the Palæontographical Society. While the mass of the Limestone is Middle Devonian, part of it is regarded as probably Upper Devonian by Mr. Ussher. An interesting coral-breccia was noted by him.

After passing near the Watcombe Terra Cotta Works, the members took lunch at the "Palk Arms," and then proceeded by Easterfield Lane to the grand cliffs of New Red sandstone and conglomerate at Watcombe. A fine view was obtained of the red cliffs looking northwards towards Teignmouth and Exmouth. The Director called attention to the Teignmouth pebbles, which, as sold to the public, were polished pebbles of fossiliferous Devonian Limestone obtained from the conglomerate on the beach. The curious coating of annulated chalcedony, named beekite after Dr. Beeke, a former Dean of Bristol, was obtained on the coast.

The lowest division of the New Red Series, the Watcombe Clay, was faulted on the south against the Red Conglomerate.

Passing round to Watcombe Head, and along the northern margin of the Valley of Rocks, the path became for a time obscure; but after scrambling through a fence, and traversing some private grounds, the members reached the high road near Maidencombe House. Thence the way led through Higher Rocombe to Haccombe Cross ( 524 feet), whence a fine view of Dartmoor was obtained. After walking through the picturesque village of Coffinswell, the large gravel pit in Harpin's Brake, near Aller Farm, was visited; and farther on, past the Aller Vale 
Potteries, ${ }^{*}$ another gravel pit was seen. In both places there was much coarse flint gravel inclined towards the valley, and including in places layers of white clay, and coloured sands, which tended to correlate them with the Bovey Beds.

The members returned to Newton Abbot by Ford House.

IV.-Babbacombe and Kent's Cavern, Torguay.

By W. A. E. Ussher and A. R. Hunt.

April I6th.-The members took train to Torre Station, and were thence driven to Petitor. On arrival at Petitor rock (300 feet above sea-level) Mr. Ussher pointed out the features of the valley. The limestone knoll of Petitor was examined, and found to consist of closely matted corals. From the knoll the limestone was shown to attenuate in a narrow ridge seaward, terminating on the beach in a pinnacle of shattered limestone penetrated by infiltrated materials from the overlying New Red rocks. These New Red rocks, consisting of clays with sandy bands (really composed of triturated Devonian slates), and brecciated at the base, were seen resting directly on the limestone and faulted on the north against the breccio-conglomerates with large limestone fragments, which forms the fine, commanding crags bounding Petitor Combe on the north. Mr. Ussher pointed out the relations of the Watcombe clays to these breccio-conglomerates. The upper part of the Watcombe clays pass under the conglomerates which form the crags of Watcombe Combe, the lower beds of the clay series exposed in Petitor Combe being separated from them by an intervening mass of the conglomerate faulted down on both sides. The breccio-conglomerates pass conformably under the rubbly breccias with quartz porphyry boulders seen last Easter between Exeter and Haldon.

Turning to the Devonian rocks, Mr. Ussher showed that the lower part of the Petitor valley consisted of red Upper Devonian slates bounded by limestones on both sides. He said that the apparently horizontal character of the limestone on the south side had always been taken as evidence of an anticlinal structure broken by denudation and exposing underlying slates. From a close study of the characters of the Upper Devonian slates of the area, he had been led to doubt the truth of this anticlinal structure, which was figured by De la Beche, and after careful investigation he had discovered traces of the liver-coloured shaly limestones of Lower Dunscombe at the junction of the slates and limestones on either side, and was also fortunate enough to obtain Goniatites, including $G$. sagittarius, in them. He showed that the apparent horizontality of the limestone between Petitor Combe and Oddicombe beach was due to close zig-zag (corkscrew-like) contortions in the vertical limb of the syncline on that side, whilst the shattered character of the limestone ridge on the opposite side

* The clay here used is mostly obtained from the Bovey Beds at Kingsteignton. 


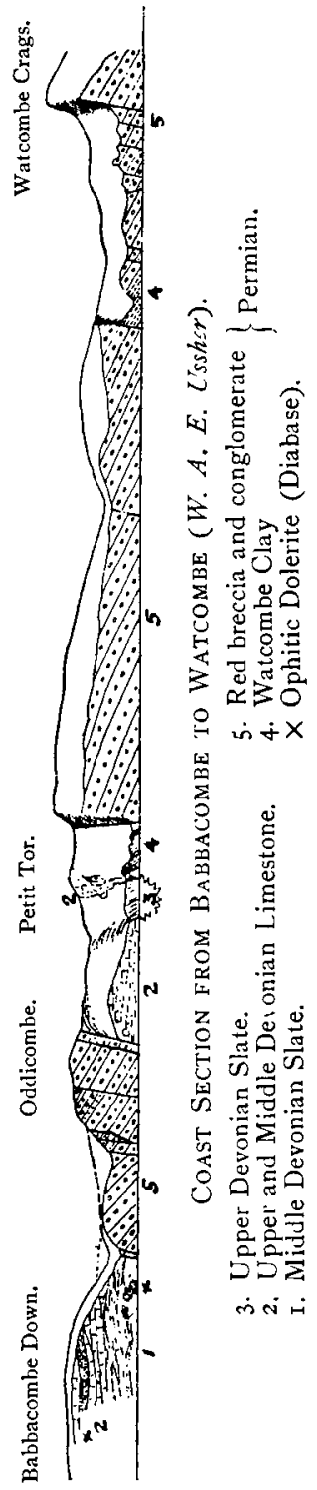

of the syncline rendered the detection of bedding planes impossible. In both limestones the structures (fibro-crystalline calcite veins) called "stromatactis" by Dupont were shown to occur; and in the intervening slates Posidonomy'a venusta, a characteristic local Upper Devonian fossil. was obtained. On reaching Oddicombe sands the party were shown a faulted junction between Devonian limestone and New Red breccio-conglomerates. In the breccio-conglomerates local beds of sand were pointed out, the junction of the materials affording pretty examples of contemporaneous erosion.

Mr. Hunt pointed out that after easterly gales Oddicombe beach often affords a good example of the general rule that large beach-shingle will travel in the direction of the wave-stroke along the beach, whereas sand and small shingle, remaining in the grasp of the wave, will travel with the current, which as likely as not is in the reverse direction. Although the Oddicombe limestone-shingle is at the foot of the New Red limestone conglomerates, the cliffs have not supplied the shingle; which is really derived from the débris tipped into the sea at the great Devonian Limestone quarry near Anstey's Cove.*

Mr. Hunt, turning to the cliffs, remarked that the conglomerates were too angular and irregular for marine action, and on too vast a scale for river action. He knew of no agency to which they could be attributed. Mr. Teall at once pointed out that similar accumulations were known in the Himalayas, where the disintegration of strata exceeded the available transport; the conglomerates were torrential Mr. Hunt observed that he had not ventured to use the word torrential for phenomena on so grand a scale, being unaware of any recent examples, but that he gratefully accepted, and fully acquiesced in Mr. Teall's explanation.

\footnotetext{
- See Trans. Roy. Dublin Soc., vol. iv, 1885 , p. 283.
} 
Mr. Ussher, in resuming, showed that the dips in the breccioconglomerates, in places amounting to over $40 \mathrm{deg}$., were due to faults. He considered that the series was the same as that of Watcombe and Petitor crags let down on either side by faults. On the south side the New Red was shown in faulted contact with dark slates visible in and at the base of the tumbled undercliff materials, as far as the Cary Arms. The party ascending the cliff by the path was shown the well-bedded limestones (Middle Devonian) of Babbacombe with a bolster-like mass of igneous rock, probably in part decomposed schalstein exposed on the axis of a uniclinal curve. In this connection Mr. Ussher pointed out the structure as a nearly vertical contact of limestones with contemporaneous igneous rock zigzagged by numerous folds, and dark slates with masses of ophitic dolerite (diabase) probably intrusive in them in several places. These bedded limestones and dark slates, he said, were lower in the series than the Petitor limestones on the north and the massive limestones of the Cary Arms coast against which they are faulted on the south; a patch of decomposed and broken red igneous rock at the little boat pier at the Cary Arms being in the vicinity of the fault.

After much needed refreshment at the Cary Arms, the party ascended the hill to the level of Babbacombe Downs, under the guidance of Mr. Hunt, and observed a shallow valley about 400 feet across, draining landwards, it having been truncated by the erosion of the great West Bay. This valley passes at the foot of the Kent's cavern hill and debouches into Torbay. It completely isolates the limestone plateau between Babbacombe and Anstey's Cove. This plateau is the highest of a series described by Pengelly as terraces of denudation, which further occur in descending order, at Daddy Hole Plain, Waldon Hill, and Berry Head, in which neighbourhood Permian dykes are levelled with the limestone, indicating that the era of denudation is postPermian. In the Walls Hill quarry, through which the valley passes, the Association examined the process of the formation of caves by the enlargement of joint planes, and the origin of cavern accumulations by the infilling of clay, with occasional foreign pebbles, from the surface of the plateau; the arrival of the pebbles on the isolated plateau apparently antedating the erosion of the shallow truncated valley. The limestone was seen to be traversed by joint planes intersecting roughly in the direction north and south, and east and west, perhaps more nearly north-east and south-west.

At Anstey's Cove the party was divided, and Mr. Hunt conducted the first division to Kent's Ca vern. While the candles were being prepared, he mentioned some of the surprising theories of cavern critics, e.g., that the extinct cave-mammalia were introduced by the Romans to work in the mines :*6 On entering the cave the visitors assembled in the Great Chamber. 
Large as it is, it must on no account be taken as representative of the cavern as a whole; as in it the two most interesting and ancient deposits-the crystalline stalagmite and its subjacent breccia--did not occur at all; nor was their existence suspected until after the Great Chamber had been explored. Passing through this chamber the party entered in single file the "Gallery," to inspect an interesting basin with corrugated sides and divisions formed by the ripples created by falling drops of water. This is the very latest stalagmite in the cave, as it was in process of formation when the explorers found it. The "Gallery" is crossed by a ceiling of the old stalagmite and its history is as follows : First nearly filled with "breccia," this deposit was covered by an old stalagmite floor. The breccia was cleared out and "cave-earth" introduced. The cave-earth in turn was covered by the newer stalagmite, under the older. This little chamber nonplussed the early explorers, who were naturally entirely ignorant of the existence of the ancient stalagmite and breccia. Leaving the "Gallery," the party passed in single file into the "Water Gallery," under the ancient stalagmite floor, in which bones of bear are embedded. At this spot there occurred the first "palæolith" flint-fragments which so astounded the explorers.* After a glance at the vestibule, the site of the "black band," and its bone tools, the party proceeded to the Wolf's Den, where MacEnery found Macharodus latidens; a find greatly discredited until the British Association Committee found another tooth of this sabre-toothed tiger in the I.ong Arcade further on in the Cavern; a find of more value as reinstating the credit of MacEnery than for the interest attaching to the great carnivore itself. The party then examined the Bear's Den; a chamber which greatly puzzled MacEnery, ignorant of the fact that he was dealing with a far more ancient stalagmite than he had investigated in other parts of the cave. From the Bear's Den the visitors proceeded to the Rocky Chamber, noticing the famous " Hedges' Boss" on the way. The Rocky Chamber, investigated late in the explorations, has scarcely received the attention it deserves, as the pipe-like stalagmites springıng from larger bosses seem to indicate a considerable variation in the rate of accumulation of carbonate of lime at some unknown period of the cavern's history. In considering the question of the Kent's Cavern stalagmites, it is well to bear in mind that the atmosphere being saturated, there is no evaporation; that the formation of stalagmite there is a question of a little more or less carbonic acid in the water, and a difference of a few degrees of temperature in the cave. Whether the incoming water will corrode the limestone, or deposit carbonate of lime, apparently depends on whether the lime-charged water enters an atmosphere cooler or warmer than itself. In the former case it may dissolve, in the latter deposit.

- See Trans. Devon Assoc., vol. v, p. 263 . 


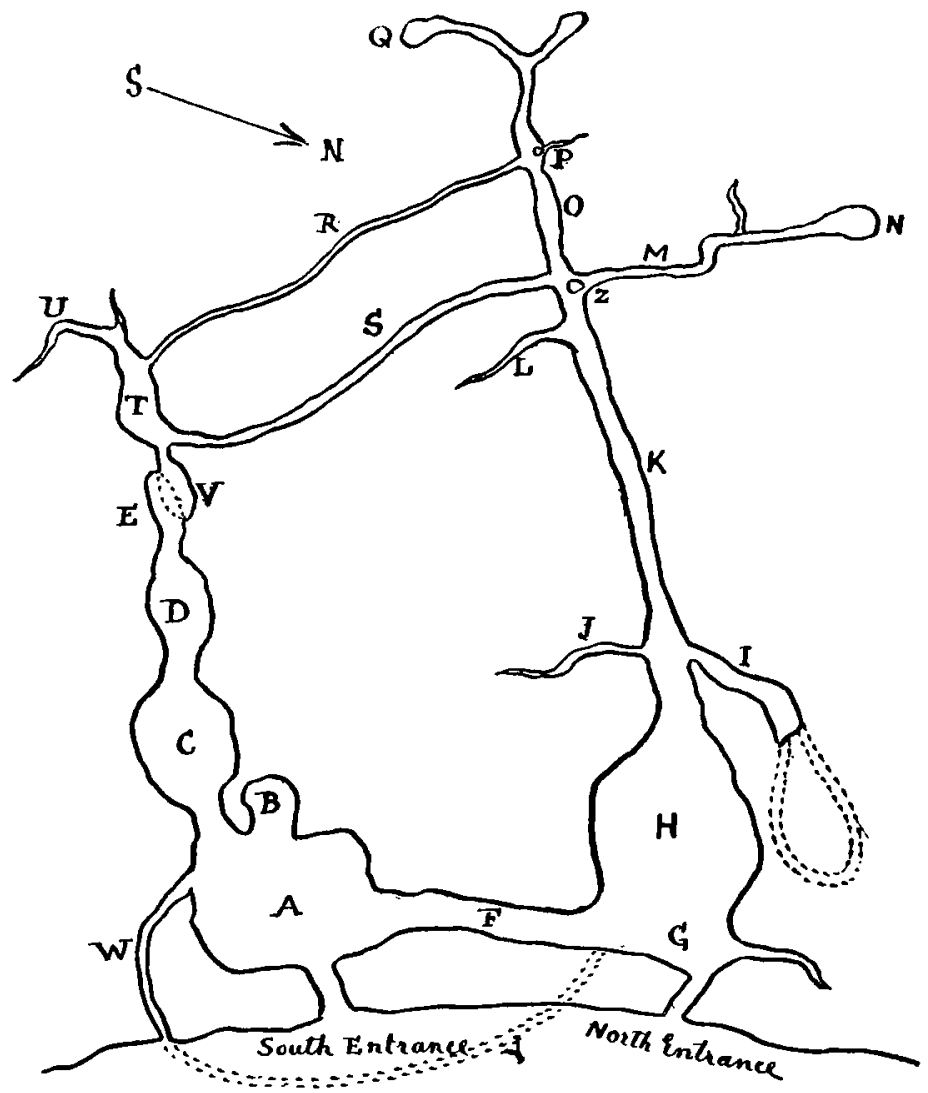

Rough Sketch Plan of Kent's Cavern (A. R. Hunt).
A. Great Chamber.
B. Gallery.
C. Lecture Hall.
D. S.W. Chamber.
E. Water Gallery.
F. Passage of Urns.
G. Vestibule.
H. Sloping Chamber.
I. Wolf's Den.
J. Charcoal Cave.
K. Long Arcade.
L. Underhay's Gallery.
M. Clinnick's Gallery.
N. Rocky Chamber.
O. Cave of Inscriptions.
P. Hedges' Boss.
Q. Swallow Gallery.
R. Great Oven

S. Labyrinth.

T. Bear's Den.

U. Tortuous Gallery.

V. Lake\& Crypt of Dates

W. North Sally Port.

$X$. Underground

Passage.

Y. Smerdon's Passage.

Z. Inscribed Boss.

Although the plan of Kent's Cavern makes no claim to accuracy, it may be as well to mention that there is a slip in the passage to $Q$ (the Swallow Gallery), the passage actually starting as a continuation of $R$ (the Great Oven), instead of as a continuation of $O$ (the Cave of Inscriptions). 
The most impressive facts in the cavern are the rocky crystalline stalagmite and the spongy porous stalagmite. They seem to tell of slow climatic changes of incalculable duration. The eroded valleys tell a like story. The advent and disappearance of the hyæna, as a short episode in the cave history may give us pause; but the stalagmites cannot be regarded as indices of time-gaps. We need not expect either man or beast to inhabit by choice the wettest portions of the cavern, or to find many bones in stalagmite; but as a matter of fact bones of bears were found throughout the ancient floor, and hyæna, rhinoceros, and others in the newer floor, close up to the surface.

Nearly eighty implements and fragments were found in the breccia." Pengelly calls them "nodule" tools, as distinguished from the cave-earth palrolithic tools, which are trimmed flakes, whereas the breccia tools are trimmed nodules. The fact is, that in Kent's Cavern we have two epochs of palæoliths, with an amount of time supposed to be represented by 12 feet of stalagmite $+x$ years between them. There is no proof that the breccia type of tool was ever made in the cave-earth era. Of course a "cave-earth" man might find a "breccia" tool, just as we ourselves might at the present time.

Before the first party had seen the cavern, the second party was ready to enter, but unfortunately time was running very short, and their inspection was somewhat hurried.

In Anstey's Cove Mr. Ussher showed that the red and green slates as at Petitor were newer than the limestones which they seemed to underlie, and at the junction with them exhibited evidence of the presence of the liver-coloured Goniatite beds. On Redgate beach the eyes of the party were gladdened by a comparatively simple series of curves, bringing the beds at the base of the fine cliff to its crest in convolutions of different degrees of intensity; but this glimmer of simple fact was soon clouded over when it was pointed out to them that limestones of different horizons in the mass were brought together by faults at either end of the beach along the projecting cliff faces, and by faults parallel to the main cliff, crossed and shifted. There was hardly time to deal with more than five or six of these, when it was found advisable to proceed to the cavern from which the first party soon emerged.

The Rev. G. F. Whidborne led a small party to Hope's Nose, where they lad the opportunity of glancing at the Raised Beach.

The members now proceeded to the Torquay Museum, and examined the fine collection of local fossils. After which they were entertained to tea by the Committee of the Torquay Natural History Society. Before parting, Mr. Whitaker, the President of the Association, proposed a hearty vote of thanks to the Torquay

* See Trans. Dezion Assoc., vol. xiv, p. 685. 
Natural History Society for their hospitality, which was greatly appreciated, and he also returned thanks to Mr. Hunt and Mr. Ussher for their services as Directors on this and other occasions. Mr. Boase, President of the Torquay Natural History Society, and Mr. Hunt briefly replied.

In contrast to the proceedings under the guidance of Mr. Hunt, Mr. Woodward (in seconding the vote of thanks) referred to the visit paid to "Kent's Hole," in I794, by Mr. W. G. Maton, F.L.S., who thus wrote: "Two women, whose usual business it is, conducted us to the spot, provided with candles, tinder-boxes, and other necessaries for the expedition. After pursuing rather an intricate track, we arrived at the mouth of the cavern. . . . The aperture was just large enough to admit us. .. . We began to fancy ourselves in the abode of some magician, or (as our companions were two ancient females, and not the most comely of their years) in the clutches of some mischievous old witches. . ... The roof is in some places so low we were obliged to advance on our knees."**

\section{V.-Newton AbBot, East OgWell, and Wolborovgh.}

By H. B. WOODWARD.

On Tuesday, April 17 th, the members started by Mill Lane and past the Bradley Manor House on the borders of the River Lemon, where in the bed of the stream the Director had found a polished stone-implement. After a pleasant walk along the wooded ravine the quarries on the north side of the valley in Broadridge Wood, and near Chircombe Bridge, where the Middle Devonian Limestones are well exposed, were visited. Crossing the bridge, and taking the path on the south side of the stream, an old limestone quarry was next visited, and then the scarp was ascended to the Pulpit Rock. Here the Limestone yields in abundance the Coral, Favosites (Pachypora) polymorpha. Occupying the pulpit the Director made some general remarks on the Devonian series, on the pioneering work of Godwin-Austen, and on the difficulties met with in Devonshire. Lonsdale's original observations (dating back to 1837 ) on the Devonian system were referred to, and it was pointed out that his suggestion of a formation intermediate between the Silurian and Carboniferous was based on a study of the fossils of the South Devon limestones. Neither the top nor the base of the Devonian system was then defined.

Reference was made to the subsequent work of Holl, and more especially to that of Champernowne, Mr. Ussher, and the Rev. G. F. Whidborne.

The difficulties in determining the sequence of the local Devonian rocks were very great, owing to the irregularities of the strata, and the great disturbances to which they had been subjected. The fossils, too, were more often than not crushed and badly preserved. Light, however, had been obtained by studying the

\footnotetext{
* "Observations relative chiefly to the Natural History, etc., of the Western Counties of
England," I797, p. I 1 .
} 
divisions made in Germany, and by applying the zonal succession there established to the elucidation of the Devonian sequence in this country. Different stratigraphical divisions must, however, be made in this country, as abroad, where the Franco-Belgian grouping differed from that in Germany.

As Mr. Ussher had pointed out, the Middle and Upper Devonian Beds were to some extent locally represented by a mass of limestones in which no definite plane of division could be made. Thus we had the lower portions of the limestoneseries at Chircombe Bridge, and an ascending series as we passed eastwards through Bradley Woods to Ramsleigh.

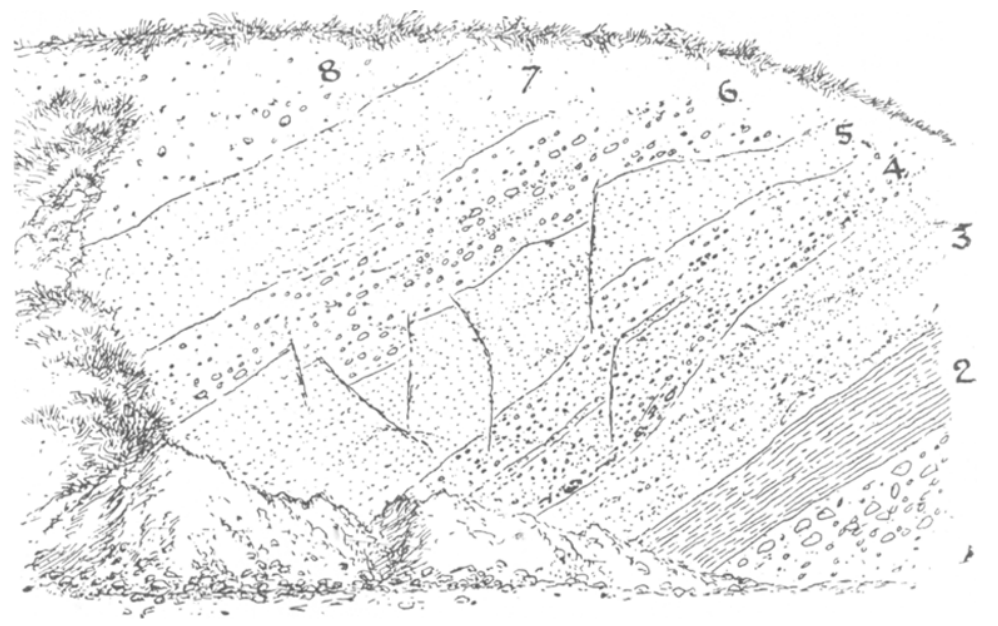

Section at Wolborough Church, Newton Abbot.

(H. B. Woodward, I896.)

$$
\text { BOVEY } \begin{cases}\text { 8. Gravel and sand. } & \text { 4. Sand and fine gravel. } \\ \text { 7. Reddish sand. } & \text { 3. Sand. } \\ 6 . \text { Gravel and sand. } & \text { 2. Clay. } \\ 5 . \text { Reddish sand. } & \text { 1. Coarse gravel. } \\ \text { Height of section about } 30 \text { feet. Length, } 60 \text { yards. }\end{cases}
$$

Returning along the top of West Hill the members now took the lane to East Ogwell, crossing the decomposed schalsteins and limestone, and also slates, on the way to Ramsleigh or Ransley quarry on East Hill. Here the limestone, as observed by Champernowne, represented the Frasnian stage of the Upper Devonian, and was characterised by Rhynchonella cuboides and Acervularia pentagona. Many examples of the "stromatactis," previously referred to, were noticed in this quarry. Eastwards the limestone is brought abruptly against Culm-measures, which were seen in the road-cutting. Thence the party proceeded bv 
Ogwell Cross to the quarry near Prospect Cottages, Wolborough, where the Middle Devonian Limestone is much stained with ferruginous matter derived from the New Red beds.

Phacops Latifrons, Bronteus flabellifer, Goniatites, Orthoceras, Stringocephalus burtini, Spirifera verneuili, Rhynchonella pugnus, and Atrypa reticularis have been recorded from Wolborough.

The gravel pit by Wolborough Church (175 feet above sealevel) next attracted attention. Here the beds dip towards the S.E. at from $35^{\circ}$ to $45^{\circ}$. The presence of coloured sands and white clays and the high inclination tended to associate the beds with those seen at Staple Hill and Aller Vale, and to support Mr. Clement Reid's contention that all were Bovey Beds.

The Director remarked that during his stay in Newton Abbot, I874-75, he was sorely perplexed with these and other sands and gravels. Eventually he came to the conclusion that they were drifts, and that there was some connection between the plateaugravels of Haldon and those which occurred with this high marginal dip in the Bovey Basin.* Now Mr. Reid had thrown light on the subject. He had traced the extension of the Bagshot Beds on to Haldon, into the very plateau gravels.t

On the other hand it is right to mention that Mr. A. E. Salter has regarded the deposits on Wolborough Hill and Milber Down as "Lower Level Plateau Gravels," derived in part from the Haldons. $t$

The members now proceeded by the Newton College recreation ground to the Decoy Clay pits belonging to the Devon and Courtenay Brick, Tile, and Clay Co. Here, as pointed out long ago by $f$. H. Key, the beds have a considerable inclination towards the east, and both clays and thin lignites have been exposed. The clays have been worked to a depth of 90 feet in some parts, the workings extending along the strike of the highly inclined beds. Intercalated in the mass of pipe-clays are occasional layers of sand. The clay is mostly white or pale grey, but it has pink staining in places, like the coloured clays of the Bagshot Beds in Dorsetshire.

The members now returned to the Globe Hotel, and the Easter excursion of I 900 came to an end.

\section{REFERENCES.}

Geological Survey Map, New Series, Sheet 339, Newton Abbot, Chudleigh, and Bovey Tracey; Sheet 350, Torquay. OLD SERIkS, Sheets 22 and 25 .

I880. Champernowne, A.-" Upper Devonian in Devorshire." Geol Mag., Dec. ii, vol. vii, p. 359.

\footnotetext{
* Quart. Jourr. Geol. Soc., vol. xxxii, p, 234.

+ Ibid., vol. liv, p. 235 .

I Proc. Geol. Assoc, vol. xv, p. 282.
}

Proc. Geol. Assoc., Vol. XVI, Part 8, July, igoo. 
1868. Holl, DR. H. B.- "On the Older Rocks of South Devon and East Cornwall." Quart. Fourn. Geol. Soc., vol. xxiv, p. 400.

1894. HuNT, A. R.- "Four Theories of the Age and Origin of the Dartmoor Granites."-Geol. Mag., Dec. iv, vol. i, p. 97.

I897. - "West Country Geological Problems. Part II. The Dartmoor Granite." Trans. Devon Assoc., vol. xxix, p. 390.

I899. - "Notes on certain Granitoid Fragments from the Culm Conglomerates, and Tourmalinized Grits from the New Red Conglomerates of South Devon." Geol. Mag., Dec. iv, vol. vi, p. 256.

1862. KEY, J. H.- "On the Bovey Deposit." Quart. Fourn. Geol. Soc., vol. xviii, p. 9.

I893. McMahon, Lieut.-Gen. C. A.- "Notes on Dartmoor." Quart, Fourn. Geol. Soc., vol. xlix, p. 385.

1863. Pengelly, W, and the Rev. Oswald Heer.- "On the Lignite Formation of Bovey Tracey, Devonshire." Phil. Trans. for I862; reprinted with prefatory remarks, 4to. London, 1863 .

- (Various papers and reports on Kent's Cavern.) See Index of vol. xvi of the Trans. Devon Assoc.

I877. REID, C.- "On the Junction of the Limestone and Culm-measures at Chudleigh." Geol. Mag., Dec. ii, vol. iv, pp. 454, 455. See also vol. vii (I880), p. 286.

I898. "The Eocene Deposits of Devon." Quart. Fourn. Geor. Soc., vol. liv, p. 234.

I880. ROEMER, DR. F. "Notice of the Occurrence of Upper Devonian Goniatite Limestone in Devonshire." Geol. Mag., Dec. ii, vol. vii, pp. I 45-1 47.

1898. SALTER, A. E.- "Pebhly and other Gravels in Southern England." Proc. Geol. Assoc., vol. xv, pp. 280-284.

1877. Ussher, W. A. E.- "The Age of the Watcombe Clay." Trans. Devon Assoc., vol. ix, p. 296.

I890. - "The Devonian Rocks of South Devon." Quart. Fourn. Geol. Soc., vol. xlvi, p. 487 .

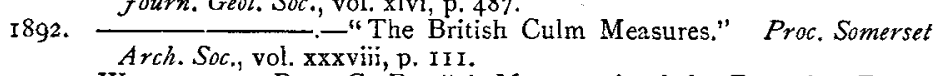

Whidborne, Rev. G. F.-"A Monograph of the Devonian Fauna of the South of England." Palaeontograph. Soc. (In progress.)

I869. WhITAKER, W.- "On the Succession of Beds in the "New Red" on the South Coast of Devon." Quart. Fourn. Geol. Soc., vol. xxv, p. $5^{2}$.

1884. WOODWARD, DR. HENRY.- "On the Discovery of Trilobites in the Culm-Shales of South-East Devonshire." Geol. Mag., Dec. iii, vol. i, pp. 534-545.

I876. WOODWARD, H. B.-- Notes on the Gravels, Sands, and other Superficial Deposits in the Neighbourhood of Newton Abbot, Devonshire." Quart. Fourn. Geol. Soc., vol. xxxii, p. 230.

1887. shire. "Geology of England and Wales" (Second Edition), pp. 1 30, 196, 233,442,494, 545. (References will here be found to the works of earlier observers.) 
Proc. Geol. Assoc., 1900,

Vol. XVI, Plate XII

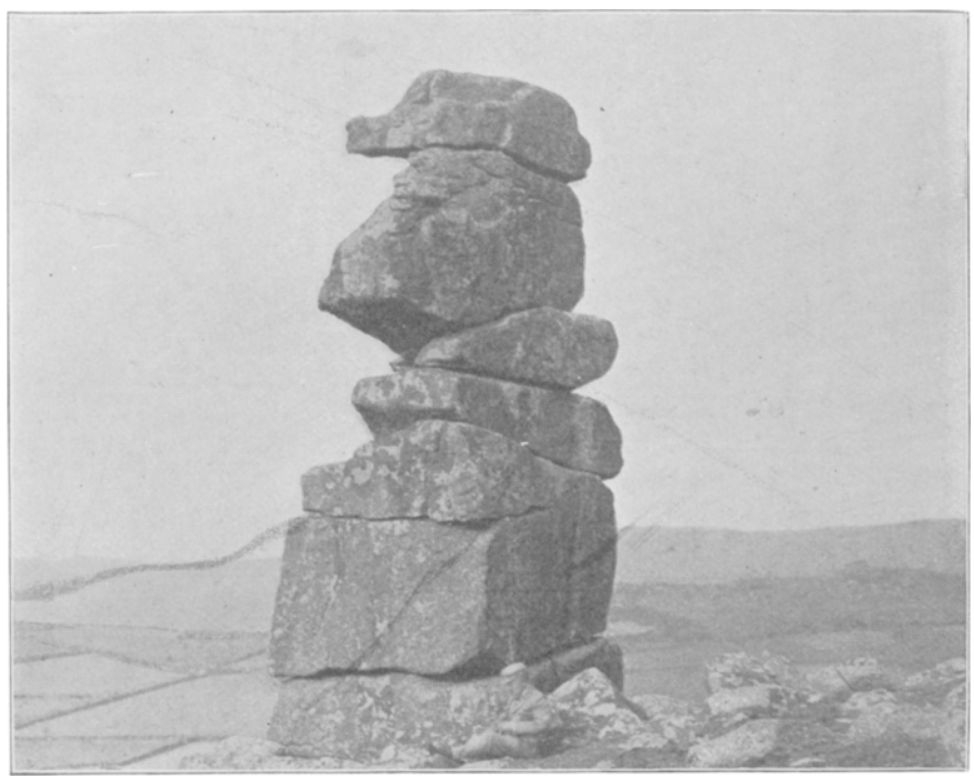

Fig. 1. - Bowerman's Nose. NEar Lustleigh. (From a Photograph by H. Preston, F.G.S.)

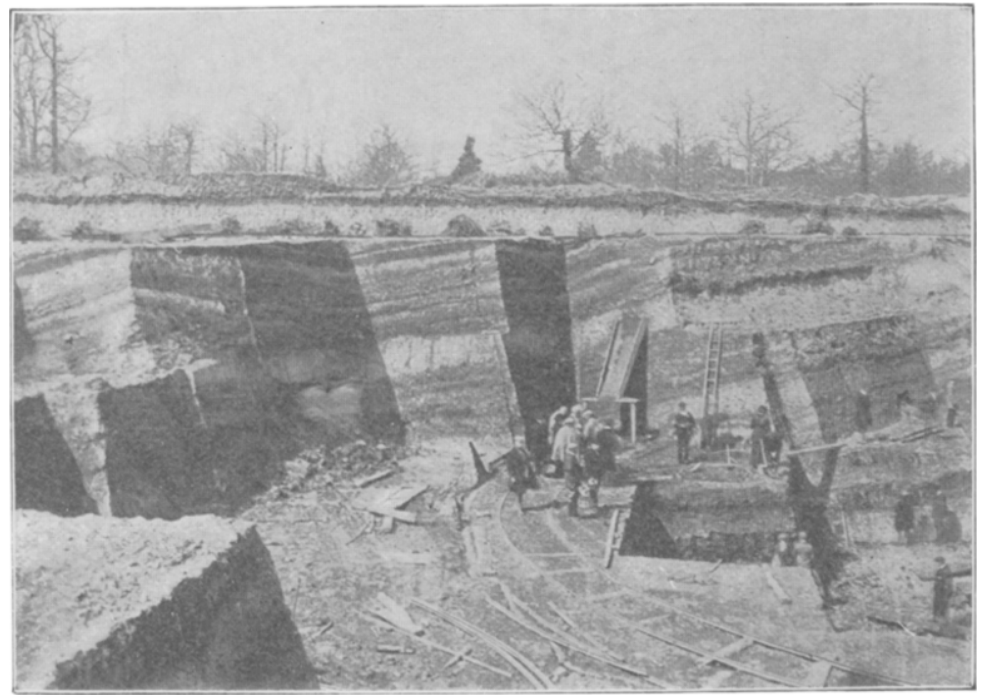

Fig. 2.-Lignite Pit, North of Preston, Kingsteignton. (From a Photograph by A. K. Coomara Swamy, F G.S.). 